\title{
Age and Body Condition of Goats Influence Consumption of Juniper and Monoterpene-Treated Feed
}

\author{
Rachel A. Frost, ${ }^{1}$ Karen L. Launchbaugh, ${ }^{2}$ and Charles A. Taylor, Jr. ${ }^{3}$ \\ Authors are ${ }^{1}$ Post Doctoral Research and Extension Associate, Animal and Range Sciences Department, Montana State University, Bozeman, MT 59717; \\ ${ }^{2}$ Associate Professor, Department of Rangeland Ecology and Management, University of Idaho, Moscow, ID 83844; and ${ }^{3}$ Professor, Texas Agricultural \\ Experiment Station, Sonora, TX 76950.
}

\begin{abstract}
Redberry juniper (Juniperus pinchotii Sudworth) is an invasive, evergreen tree that is rapidly expanding throughout western and central Texas. Goats will consume some juniper on rangelands; however, intake is limited. The objective of our research was to determine how the age and body condition of goats influence their consumption of juniper and an artificial feed containing 4 monoterpenes. Two separate experiments were conducted. Experiment 1 examined the intake of redberry juniper foliage and used 39 goats either young $(2 \mathrm{yr})$ or mature $(>6 \mathrm{yr})$. One-half of each age group was fed appropriate basal rations to reach either a high $(\mathrm{HBC})$ or low body condition (LBC). Goats in $\mathrm{LBC}$ ate more $\left(P<0.01,8.6 \mathrm{~g} \cdot \mathrm{kg}^{-1}\right.$ body weight $\left.[\mathrm{BW}] \pm 0.7 \mathrm{SE}\right)$ juniper than those in $\mathrm{HBC}$ $\left(2.3 \mathrm{~g} \cdot \mathrm{kg}^{-1} \mathrm{BW} \pm 0.3 \mathrm{SE}\right)$, and young animals consumed more $\left(P<0.05,7.2 \mathrm{~g} \cdot \mathrm{kg}^{-1} \mathrm{BW} \pm 0.7 \mathrm{SE}\right)$ juniper than mature goats $\left(3.9 \mathrm{~g} \cdot \mathrm{kg}^{-1} \mathrm{BW} \pm 0.5 \mathrm{SE}\right)$ across body condition treatments. In experiment 2,36 goats, either young $(2 \mathrm{yr})$ or mature $(>6 \mathrm{yr})$ and in either $\mathrm{HBC}$ or $\mathrm{LBC}$, were offered a synthetic ration treated with $20.8 \mathrm{~g} \cdot \mathrm{kg}^{-1}$ of 4 monoterpenes found in redberry juniper. Goats in $\mathrm{LBC}$ ate more $\left(P<0.01,25.3 \mathrm{~g} \cdot \mathrm{kg}^{-1} \mathrm{BW} \pm 1.0 \mathrm{SE}\right)$ of the terpene-treated feed than those in $\mathrm{HBC}\left(17.5 \mathrm{~g} \cdot \mathrm{kg}^{-1} \mathrm{BW} \pm 0.7 \mathrm{SE}\right)$, and young animals ate more $\left(P<0.05,22.5 \mathrm{~g} \cdot \mathrm{kg}^{-1} \mathrm{BW} \pm 0.8 \mathrm{SE}\right)$ than mature goats $\left(20.3 \mathrm{~g} \cdot \mathrm{kg}^{-1} \mathrm{BW} \pm 0.8 \mathrm{SE}\right)$ across body condition treatments. Total intake as a proportion of body weight was also affected by body condition. Age and body condition are important factors that influence intake of chemically defended plants. A better understanding of how these attributes affect diet selection will aid livestock producers in improving grazing management.
\end{abstract}

\section{Resumen}

"Redberry juniper" (Juniperus pinchotii Sudworth) es una especie arbórea invasora que permanece verde todo el año y que se esta expandiendo rápidamente a través del oeste y centro de Texas. Las cabras consumirán algo de "Juniper" en los pastizales, sin embargo, el consumo es limitado. El objetivo de nuestra investigación fue determinar como la edad y condición corporal de las cabras influye en su consumo de "Juniper" y de un alimento artificial conteniendo 4 monoterpenoides. Se condujeron dos experimentos separados, el experimento 1 examinó el consumo del follaje de "Redberry juniper"; se utilizaron 39 cabras tanto jóvenes ( 2 años) como maduras (mayores de 6 años). Los grupos fueron divididos en mitades que se alimentaron con raciones básicas para que alcanzará una condición corporal alta $(\mathrm{HBC})$ o baja (LBC). Las cabras con LBC comieron más $(P<0.01$, $8.6 \mathrm{~g} \cdot \mathrm{kg}^{-1}$ peso vivo [PV] $\left.\pm 0.7 \mathrm{EE}\right)$ "Juniper" que las de $\mathrm{HBC}\left(2.3 \mathrm{~g} \cdot \mathrm{kg}^{-1} \mathrm{PV} \pm 0.3 \mathrm{EE}\right)$ y los animales jóvenes consumieron más de esta especie $\left(P<0.05,7.2 \mathrm{~g} \cdot \mathrm{kg}^{-1} \mathrm{PV} \pm 0.7 \mathrm{EE}\right)$ que las cabras maduras $\left(3.9 \mathrm{~g} \cdot \mathrm{kg}^{-1} \mathrm{PV} \pm 0.5 \mathrm{EE}\right)$, promediando los tratamientos de condición corporal. En el experimento 2, 36 cabras, tanto jóvenes ( 2 años) como maduras (mayores a 6 años) en condición HBC o LBC, fueron expuestas a una ración sintética tratada con $20.8 \mathrm{~g} \cdot \mathrm{kg}^{-1}$ de 4 monoterpenoides encontrados en el "Redberry juniper." Las cabras con LBC comieron más $\left(P<0.01,25.3 \mathrm{~g} \cdot \mathrm{kg}^{-1} \mathrm{PV} \pm 1.0 \mathrm{EE}\right)$ alimento tratado con los monoterpenoides que aquellas con $\mathrm{HBC}\left(17.5 \mathrm{~g} \cdot \mathrm{kg}^{-1} \mathrm{PV} \pm 0.7 \mathrm{EE}\right)$, y promediando los tratamientos de condición corporal, los animales jóvenes consumieron más $\left(P<0.05,22.5 \mathrm{~g} \cdot \mathrm{kg}^{-1} \mathrm{PV} \pm 0.8 \mathrm{SE}\right)$ que las cabras maduras $\left(20.3 \mathrm{~g} \cdot \mathrm{kg}^{-1} \mathrm{PV} \pm 0.8 \mathrm{SE}\right)$. El consumo total, como proporción del peso vivo, también fue afectado por la condición corporal. La edad y condición corporal son factores importantes que influyen en el consumo de plantas con defensas químicas. El entender mejor como estos atributos afectan la selección de la dieta ayudará a los ganaderos a mejorar el manejo del apacentamiento.

Key Words: intake, Juniperus, nutrition, terpenoids

This project was supported by the Initiative for Future Agriculture and Food Systems Grant 2001-52103-11215 from the US Dept of Agriculture Cooperative State Research, Education, and Extension Service.

The use of trade, form, or corporation names in this publication is for the information and convenience of the reader. Such use does not constitute an official endorsement or approval by the US Department of Agriculture or the authors of any product or service to the exclusion of others that may be suitable.

At the time of the research, Frost was research assistant, Dept of Rangeland Ecology and Management, University of Idaho, Moscow, ID 83844.

Correspondence: Rachel A. Frost, Animal and Range Sciences Dept, Montana State University, Bozeman, MT 59717. Email: frost@montana.edu

Manuscript received 22 November 2006; manuscript accepted 3 September 2007.

\section{INTRODUCTION}

Redberry juniper (Juniperus pinchotii Sudworth) is an invasive evergreen tree that has been rapidly expanding throughout western and central Texas since the early 1900s (McPherson and Wright 1990). This small tree is an aggressive competitor with a dense branch pattern that intercepts precipitation before it reaches the soil and has an effective lateral root system that suppresses growth of adjacent grasses and forbs, thereby, increasing the amount of bare ground. This causes a dramatic decline in the herbaceous forage for livestock and wildlife while 
creating conditions that further perpetuate the establishment of juniper (Dye et al. 1995).

Prescribed browsing by domestic goats has been suggested as a method of controlling juniper invasion, even though it contains monoterpenes or essential oils, which inhibit herbivory in several ways. First, monoterpenes exhibit antimicrobial properties that vary by concentration (Oh et al. 1967; Nagy and Tengerdy 1968) and class of monoterpenes (Oh et al. 1968). Secondly, monoterpenes limit intake presumably by producing conditioned flavor aversions from digestive malaise or illness following consumption (Estell et al. 1998, 2002; Vourc'h et al. 2002). Monoterpenes found in juniper have been negatively correlated with preference by herbivores (Riddle et al. 1996).

Monoterpenes are lipophilic compounds that must be converted to hydrophilic substances to be excreted from the body. This conversion process occurs in the liver and requires energy and nutritional resources (Foley et al. 1995). As body condition declines, animals lose functioning liver mass (Noziere et al. 1999), further diminishing their ability to process plant allelochemicals. Foley and colleagues (1995) contend that animals under nutritional stress may need to adjust their foraging strategy by decreasing consumption of toxic plants to maintain homeostasis. They propose that concentrations of secondary plant compounds set intake limits, and animals with compromised detoxification capacity should exhibit reduced intake of plants containing secondary compounds. But, recent research with cattle in low body condition has demonstrated that herbivores may behave otherwise. Cattle in low body condition began consuming a toxic lupine species (Lupinus argenteus Pursh) sooner and ingested greater quantities overall than those in average body condition (Lopez-Ortiz et al. 2007). It is well established that animals in low body condition typically increase dry matter intake. For example, thin cattle consume $24 \%$ more feed than fat cattle (Bines and Morant 1983), and thin ewes eat more than fat ewes and spend more time foraging (Arnold and Birrell 1977; Sibbald and Kerr 1994; Sibbald 1997). However, this need to increase intake can result in the inclusion of less palatable, or even toxic, plants in the diet (Mellado et al. 2004).

Age also influences diet selection. Young animals face unique foraging challenges because of their greater nutritional requirements and lack of foraging experience (Provenza and Malechek 1986). A mammal's metabolic rate declines with age (Henry 2000), so older animals do not need as much food and consequently graze less, whereas young animals generally spend more time foraging and less time ruminating (Dunn et al. 1988; Cazcarra and Petit 1995). These conditions necessitate the selection of more digestible diets by younger animals (Hodgson and Jamieson 1981). Thus, it seems that young browsing animals would include less low-quality forage, like juniper, in their diets than older animals, unless alternative forages were limited. Age exerts the greatest influence on diet selection when animals $<18$ mo old are compared with animals that are $>2 \mathrm{yr}$ old (Hodgson and Jamieson 1981; Provenza and Malechek 1986; Grings et al. 2001). However, differences in grazing behavior and intake exist between age classes of sexually mature animals. Dunn and colleagues (1988) demonstrated that 3-yr-old cattle spent more time grazing than 5-7-yr-old cattle. Similarly, Langlands (1968) found that intake of herbage in sheep increased till approximately $3 \mathrm{yr}$ old and declined thereafter. The purpose of this research was to determine whether age and body condition influenced the consumption of live redberry juniper foliage or intake of an artificial feed in which 4 monoterpenes found in redberry juniper were added.

\section{MATERIALS AND METHODS}

\section{Experiment 1-Intake of Juniper Foliage}

Conditioning Period. Research was conducted at the Texas A\&M University (TAMU) Agricultural Experiment Station, $52 \mathrm{~km}$ south of Sonora, TX. Thirty-nine female Boer-Spanish crossbred goats were selected from a herd grazing on juniperinfested rangeland. Goats were chosen from 2 age groups: young $(\mathrm{Y})$ were $2 \mathrm{yr}$ old $(n=20)$, and mature goats $(\mathrm{M})$ were greater than 6 yr of age $(n=19)$. We chose these age groups to explore how managers might divide their flocks into functional groups with potential differences in diet selection, especially consumption of chemically defended plants. Half of each age group was randomly assigned to either a high or low body condition (HBC or LBC, respectively) treatment, resulting in four treatment combinations of age and body condition. The goats were maintained in individual pens with free-choice access to water and trace-mineralized salt. Those animals in the HBC treatment groups were offered ad libitum access to an above-maintenance complete ration, whereas those assigned to the LBC treatment received $1.5 \%$ body weight (BW) of a belowmaintenance ration offered at 0700 and 1700 hours each day in two equal allotments (Table 1 ). All weights and amounts of feed were determined and are expressed on an as-fed basis. Body condition was evaluated both by touch (tactile) and visual observation (scored on a 1 to 5 scale) once a week by two trained technicians, one of which was blind to the treatments (Spahr 2004). After a 10-wk conditioning period, those animals in the HBC group had an average body condition score of $3.7 \pm 0.1 \mathrm{SE}$, whereas those in $\mathrm{LBC}$ averaged $1.4 \pm 0.1 \mathrm{SE}$. Weights of the treatment groups were MHBC, $51.5 \mathrm{~kg} \pm 4.0 \mathrm{SE}$; MLBC, $33.4 \mathrm{~kg} \pm 1.6 \mathrm{SE}$; YHBC, $40.4 \mathrm{~kg} \pm 1.1 \mathrm{SE}$; and YLBC, $25.3 \mathrm{~kg} \pm 0.7 \mathrm{SE}$. All animal experimental protocol was approved by the Texas A\&M University Animal Use and Care Committee (AUP2033-136).

Experimental Period. Five days before the experiment, all animals were converted to a daily ration of $2.0 \% \mathrm{BW}$ of alfalfa pellets divided into two equal allotments fed at 0700 and 1700 hours. Three days before the experiment, all goats were offered ad libitum access to juniper foliage for $1 \mathrm{~h}$. Those $3 \mathrm{~d}$ were used as a training period to familiarize the goats with juniper and the testing schedule. The goats were maintained in individual pens with continuous access to water and shade. Redberry juniper branches were harvested daily, the leaves were stripped from the branches by hand, and amounts in excess of intake were offered to each goat from 0900 until 1300 hours each day for $5 \mathrm{~d}$. Orts were collected and adjusted for moisture loss, which was estimated by placing two feed troughs with $250 \mathrm{~g}$ fresh juniper outside the pens each day during the trial. 
Table 1. Nutrient composition of mixed rations fed to goats in high body condition $(\mathrm{HBC})$ or low body condition ( $\mathrm{LBC}$ ) treatments during conditioning period. Animals in the HBC treatment had ad libitum access to the feed for a 10-wk conditioning period, whereas LBC animals were offered $1.5 \%$ body weight daily (as-fed basis) for the 10 wk.

\begin{tabular}{lcc}
\hline Nutrient & HBC ration & LBC ration \\
\hline & -16.2 & 9 \\
Crude protein & 71.1 & 56.1 \\
Total digestible nutrients & 2.6 & 2.4 \\
Crude fat & 24.5 & 43.8 \\
Acid detergent fiber & 0.75 & 0.53 \\
\hline
\end{tabular}

Experimental Design and Analysis. This experiment was a $2 \times$ 2 factorial in a completely randomized design nearly balanced with 10 animals per treatment (except YLBC with nine animals). The model included body condition and age with repeated measurements over $5 \mathrm{~d}$. The data were analyzed using a General Linear Model (GLM) in SAS (SAS 2004). Effects included in the model were body condition, age, body condition $\times$ age, animal nested within body condition $\times$ age, and all possible interactions of these factors and time. Means for main effects were compared using least-squared means when a significant $\mathrm{F}$ test $(P<0.05)$ was observed.

\section{Experiment 2-Consumption of Terpene-Treated Feed}

We created an artificial diet that contained four major monoterpenes found in redberry juniper to further our understanding of how age and body condition influence intake of juniper. This experiment was conducted in a different location and used a different group of goats from experiment 1 .

Conditioning Period. The trial was conducted at the University of Idaho Sheep Research and Teaching Center near Moscow, Idaho. Thirty-six female Boer and Spanish crossbred goats were selected from two age groups: young were 2 yr old $(n=18)$ and mature goats greater than 6 yr of age $(n=18)$. Half of each age group was randomly assigned to either a HBC or LBC treatment, resulting in four treatment combinations of age and body condition. Goats were maintained in a large pen with free access to water and trace-mineralized salt, except during the feeding period when the goats were individually penned in stalls measuring $0.8 \times 1.6 \mathrm{~m}$. Animal conditioning was accomplished in an 18-wk feeding period during which LBC goats were offered an average of $1.9 \% \mathrm{BW}$ of an alfalfa-straw pellet (60\% alfalfa, $40 \%$ straw), whereas those assigned to the HBC treatment were offered an average of $2.7 \%$ BW of a diet comprising about $92 \%$ alfalfa pellets and $8 \%$ rolled barley (Table 2). Beginning in week 3, all animals were offered $100 \mathrm{~g}$ of chopped bluegrass (Poa pratensis L.) hay before their conditioning ration to provide fiber for proper rumen function.

Goats were weighed weekly, and amounts of feed were adjusted by treatment and individual to ensure timely progress toward desired body conditions. Beginning in week 15 , body condition was scored weekly on a 1-5 scale by tactile and visual estimation of body fat depositions (Spahr 2004) by 3 trained technicians who were blind to the treatments. The mean
Table 2. Neutral detergent fiber (NDF) and crude protein (CP) content of the conditioning rations, basal ration, and experimental ration used in experiment 2. Alfalfa/straw pellets and bluegrass hay $(100 \mathrm{~g})$ were fed to animals in low body condition (LBC) during the conditioning period. Alfalfa pellets, rolled barley, and bluegrass hay $(100 \mathrm{~g})$ were fed to animals in high body condition (HBC) during the conditioning period. Alfalfa pellets (1.5\% body weight) and bluegrass hay (100 g/animal) were the basal ration during the experiment. Four monoterpenes were added to the bluegrass pellets at a concentration of $20.8 \mathrm{~g} \cdot \mathrm{kg}^{-1}$ feed for the experimental ration.

\begin{tabular}{|c|c|c|}
\hline Feed & NDF & $\mathrm{CP}$ \\
\hline & \multicolumn{2}{|c|}{------------LBC conditioning ration ------------ } \\
\hline \multirow[t]{2}{*}{ Alfalfa/straw pellets } & 57.9 & 11.3 \\
\hline & \multicolumn{2}{|c|}{--------- HBC conditioning ration ---------- } \\
\hline Rolled barley & 49.3 & 14.4 \\
\hline \multirow[t]{2}{*}{ Alfalfa pellets } & 47.1 & 16.5 \\
\hline & ------------------Basal ration ------ & 5.3 \\
\hline \multirow[t]{2}{*}{ Alfalfa pellets } & 47.1 & 16.5 \\
\hline & \multicolumn{2}{|c|}{---- Experimental ration---------- } \\
\hline Bluegrass pellets & 54.6 & 10.4 \\
\hline
\end{tabular}

body condition at the end of the conditioning period was $2.0 \pm 0.1$ SE for LBC and 3.1 \pm 0.1 SE for HBC animals. Although these body condition scores were not as well defined as those in experiment 1 , they are more indicative of natural ranges that animals would undergo while grazing on rangelands. Weights of the treatment groups were $\mathrm{MHBC}$, $51.0 \mathrm{~kg} \pm 2.7 \quad \mathrm{SE} ; \quad \mathrm{MLBC}, \quad 40.4 \mathrm{~kg} \pm 2.4 \mathrm{SE} ; \quad \mathrm{YHBC}$, $44.2 \mathrm{~kg} \pm 1.1 \mathrm{SE}$; and YLBC, $34.0 \mathrm{~kg} \pm 1.4 \mathrm{SE}$. Seven days before the trial began, all animals were converted to a diet of $100 \mathrm{~g}$ of chopped bluegrass hay and $1.5 \% \mathrm{BW}$ of alfalfa pellets (Table 2).

Experimental Procedure. Goats were offered a feed treated with a mixture of 4 of the most prominent monoterpenes found in redberry juniper: $\alpha$-pinene $(13 \%)$, limonene $(58 \%)$, myrcene (24\%), and $\alpha$-terpineol (5\%). The amounts were designed to mimic the concentrations of these terpenes in live redberry juniper. The terpenes were applied to a bluegrass pelleted feed at a concentration of $20.8 \mathrm{~g}$ of monoterepenes $\cdot \mathrm{kg}^{-1}$ of feed (as-fed basis), which is double the total concentration of monoterpenes in redberry juniper foliage (Owens et al. 1998). We used a very high concentration of monoterpenes in an attempt to establish a threshold where LBC animals might have to decrease intake of the chemically defended plant. Bluegrass pellets were chosen as the carrier for the monoterpenes because they are similar to redberry juniper in forage quality (Huston et al. 1981; Table 2).

Bluegrass pellets were put into the polyethylene drum of an electric concrete mixer and rotated while the monoterpenes were applied at a coarse mist with a 3.7-L stainless-steel garden sprayer. The initial offering of $750 \mathrm{~g}$ of the treated feed was weighed into a 3.78-L polypropylene feed bucket. About 20 min elapsed from the final mixing until the feed was offered to goats. Subsequent batches of feed were mixed as needed to fulfill goat demand.

On days 1-6 of the trial, animals were offered one-third of their basal ration $(0.5 \% \mathrm{BW})$ at 0900 hours followed by a $4-\mathrm{hr}$ 
exposure to a feed treated with monoterpenes. These $6 \mathrm{~d}$ were used as a training period to familiarize the goats with the monoterpene feed and the testing schedule. The amount of monoterpene-treated feed offered was gradually increased from 500 to $1000 \mathrm{~g}$ and then reduced to $750 \mathrm{~g}$, which was determined to be the optimum amount of feed to offer.

Beginning on day 7 , the goats were offered access to the treated feed from 1100 to 1500 hours. After $4 \mathrm{hr}$, all orts were collected and weighed, and the goats were returned to a larger holding pen and allowed to drink for $30 \mathrm{~min}$. Animals were then returned to their individual pens and offered $1 \% \mathrm{BW}$ of alfalfa pellets as the remainder of their basal ration. Orts were collected and intake recorded daily for $23 \mathrm{~d}$. Difficulty in obtaining monoterpenes led to several complications during the experiment. On day 9, there were only enough monoterpenes to offer each animal $250 \mathrm{~g}$ of treated feed. On day 18, monoterpene supply was only sufficient to offer the goats $750 \mathrm{~g}$ of treated feed with only limited feed available to meet additional animal demand. On day 19, the monoterpenes were not offered until 0300 hours. Day 9 was dropped from the analysis because none of the goats were able to achieve desired intake levels; however, there was enough monoterpene-treated feed to satisfy most animals on day 18, so it remained in the analysis. Dropping day 9 from the analysis did not influence the overall results of the trial.

Feed Analysis. Samples of the monoterpene-treated feed were taken on $2 \mathrm{~d}$ that were representative of air temperature throughout the trial to quantify volatilization of the monoterpenes. The samples were collected immediately following mixing; 20 min after mixing; and 1, 2, 3, and $4 \mathrm{hr}$ after offering the feed; and frozen before analysis. The monoterpene concentration of the feeds was analyzed by liquid extraction and gas-chromatography-mass-spectrometry (GC-MS) analysis (Frost 2005).

Neutral detergent fiber (NDF) of feeds was determined by the Van Soest method (Van Soest et al. 1991), and crude protein (CP) analysis of feeds were determined by carbon/ nitrogen analysis based on the Dumas method of combustion (Sweeney 1989).

Experimental Design and Analysis. This experiment was a $2 \times$ 2 factorial in a completely randomized design with nine animals per treatment. The model included body condition and age with repeated measurements over $23 \mathrm{~d}$. The data were analyzed using a General Linear Model (GLM) in SAS (SAS 2004). Effects included in the model were body condition, age, body condition $\times$ age, animal nested within body condition $X$ age, and all possible interactions of these factors and time. Means for main effects were compared using least-squared means when a significant $\mathrm{F}$ test $(P<0.05)$ was observed.

\section{RESULTS}

\section{Experiment 1-Intake of Juniper Foliage}

All goats consumed $100 \%$ of their basal ration of alfalfa pellets and were readily accepting the juniper by day 3 of the pretrial period. Intake of juniper foliage was adjusted for moisture loss and is expressed as grams per kilograms BW. Goats in LBC ate more $(P<0.01)$ juniper than those in $\mathrm{HBC}\left(8.6 \mathrm{~g} \cdot \mathrm{kg}^{-1}\right.$

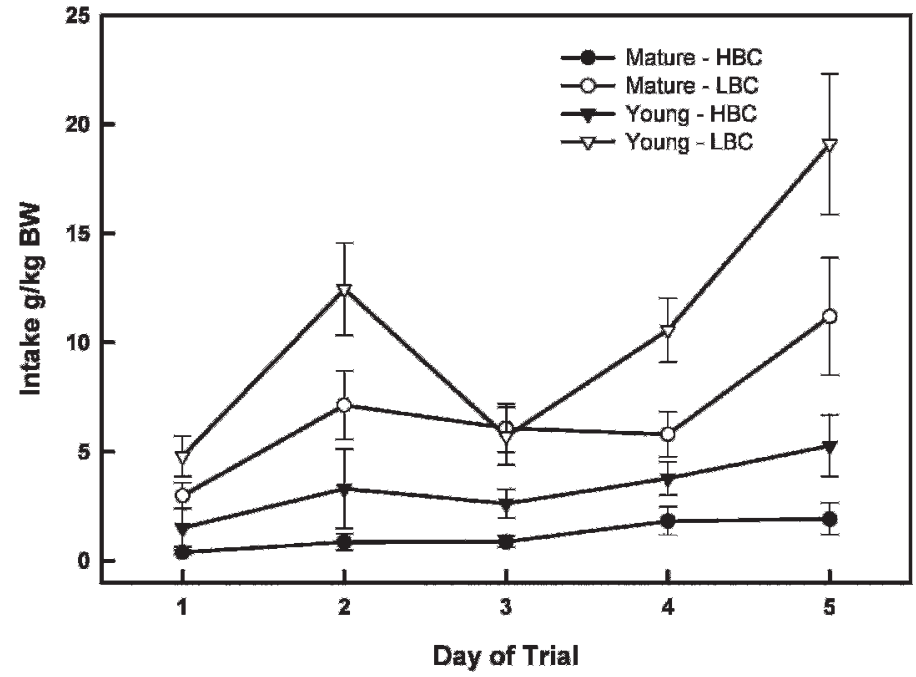

Figure 1. Mean intake of live juniper foliage by domestic goats for $5 \mathrm{~d}$. Intake was adjusted for moisture loss and expressed as grams per kilograms of body weight. Treatments were of goats in low or high body condition (LBC or HBC) either young (2 yr old) or mature (>6 yr old).

$\mathrm{BW} \pm 0.7 \mathrm{SE}$ compared with $2.3 \mathrm{~g} \cdot \mathrm{kg}^{-1} \mathrm{BW} \pm 0.3 \mathrm{SE}$, respectively), and young animals consumed more $(P<0.05)$ juniper than mature goats across body condition treatments $\left(7.2 \mathrm{~g} \cdot \mathrm{kg}^{-1} \quad \mathrm{BW} \pm 0.7 \quad \mathrm{SE}\right.$ compared with $3.9 \mathrm{~g} \cdot \mathrm{kg}^{-1}$ $\mathrm{BW} \pm 0.5 \mathrm{SE}$, respectively). Intake increased for all treatment groups throughout the 5 -d trial $(P<0.01)$. At the end of the trial period, all animals were consuming nearly 4 times the amount of juniper they had initially (Fig. 1). Goats in the YLBC treatment decreased intake on day 3 resulting in a day $\times \mathrm{BC}$ $(P<0.01)$ and day $\times$ age interaction $(P<0.05$; Fig. 1$)$.

\section{Experiment 2-Consumption of Terpene-Treated Feed}

Goats increased intake during the 6-d pretrial period and were readily accepting the feed by the first day of the trial. Goats in LBC ate more $(P<0.01)$ of the terpene-treated feed than those in $\mathrm{HBC}\left(25.3 \mathrm{~g} \cdot \mathrm{kg}^{-1} \quad \mathrm{BW} \pm 1.0 \quad \mathrm{SE}\right.$ compared with $17.5 \mathrm{~g} \cdot \mathrm{kg}^{-1} \mathrm{BW} \pm 0.7 \mathrm{SE}$, respectively; Fig. 2), and young animals ate more $(P<0.05)$ than mature goats across body condition treatments $\left(22.5 \mathrm{~g} \cdot \mathrm{kg}^{-1} \mathrm{BW} \pm 0.8 \mathrm{SE}\right.$ compared with $20.3 \mathrm{~g} \cdot \mathrm{kg}^{-1} \mathrm{BW} \pm 0.8 \mathrm{SE}$, respectively; Fig. 3). Consequently, total daily intake of monoterpenes by the LBC group $\left(0.49 \mathrm{~g} \cdot \mathrm{kg}^{-1} \mathrm{BW}\right)$ during this trial was roughly double the dose shown to create aversions $\left(0.22 \mathrm{~g} \cdot \mathrm{kg}^{-1} \mathrm{BW}\right)$ by Pritz et al. (1997). Daily intake of monoterpenes by the HBC goats $\left(0.34 \mathrm{~g} \cdot \mathrm{kg}^{-1} \mathrm{BW}\right)$ was also above the effective dose of monoterpenes.

Intake of the terpene-treated feed varied from day to day for all treatment groups throughout the trial (Figs. 2 and 3). There was a significant day $\times \mathrm{BC}$ interaction $(P<0.05)$ for days 10 and 19 , the days immediately following those with shortages of monoterpene-treated feed. No other interactions were observed.

Total daily intake of the treated feed and the basal ration combined was the same $(P=0.77)$ for both LBC and HBC goats. However, when total daily intake was examined as a percentage of body weight, the LBC goats consumed a greater 


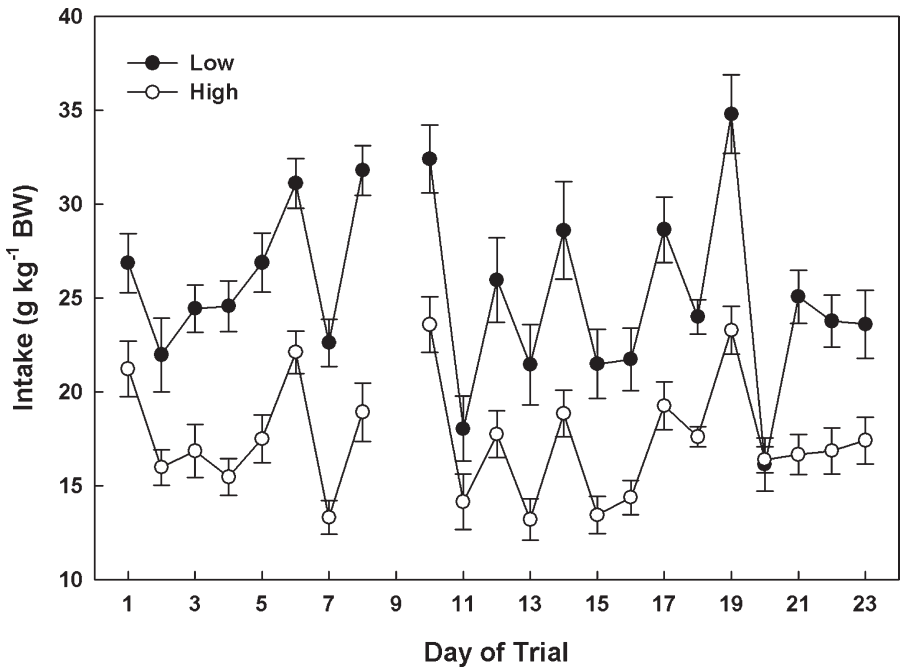

Figure 2. Mean intake of bluegrass pellets treated with $20.8 \mathrm{~g} \cdot \mathrm{kg}^{-1}$ of a monoterpene mixture. The treated pellets were offered in excess for $4 \mathrm{hr}$ for 23 consecutive days. Treatments were low body condition and high body condition. Day 9 was not included in analysis because of limited terpene availability. BW indicates body weight.

$(P<0.01)$ proportion of their body weight than the HBC goats $(4.0 \% \mathrm{BW} \pm 0.1 \mathrm{SE}$ vs. $3.2 \% \mathrm{BW} \pm 0.0 \mathrm{SE})$. Both $\mathrm{LBC}$ and $\mathrm{HBC}$ animals gained weight throughout the 23-d trial; however, animals in the LBC group gained more $(P<0.01)$ than those in the $\mathrm{HBC}$ group $\left(2.1 \mathrm{~kg} \cdot\right.$ animal $^{-1} \pm 0.5 \mathrm{SE}$ vs. $0.1 \mathrm{~kg} \cdot$ ani$\mathrm{mal}^{-1} \pm 0.5 \mathrm{SE}$, respectively).

Monoterpene Concentration of Feed. There was no decline in the concentration of monoterpenes on the feed even after $4 \mathrm{hr}$ $\left(P=0.68 ; R^{2}<0.01\right)$. The feed was treated with $20.8 \mathrm{~g} \cdot \mathrm{kg}^{-1}$, and the average monoterpene concentration detected was $19.0 \mathrm{~g} \cdot \mathrm{kg}^{-1} \pm 0.5 \mathrm{SE}$. Therefore, loss of the monoterpenes through volatilization should not have influenced intake during daily trials.

\section{DISCUSSION}

Body condition has been shown to influence dry-matter intake of foods by both cattle and sheep. Typically, animals in LBC exhibit compensatory intake when additional food becomes available. Sibbald and Kerr (1994) and Sibbald (1997) found that thin ewes had higher intake rates than fat ewes resulting from more time spent grazing. Similarly, Arnold and Birrell (1977) determined that thin sheep were able to increase intake rates over those of fat sheep by increasing biting rate and time spent grazing. When offered ad libitum access to feed, thin cattle consume $24 \%$ more food than fat cattle (Bines and Morant 1983). Likewise, cattle decrease intake (Garnsworthy and Topps 1982; Hayirli et al. 2002) and biting rate (Sprinkle et al. 2000) with increasing body condition score.

LBC of animals grazing rangelands often occurs during periods of low forage availability. Therefore, to achieve higher intake rates, animals may need to increase diet breadth and consume chemically defended foods that would normally be rejected. For example, cattle in LBC began including lupine in their diet before cattle in $\mathrm{HBC}$ and consumed greater amounts

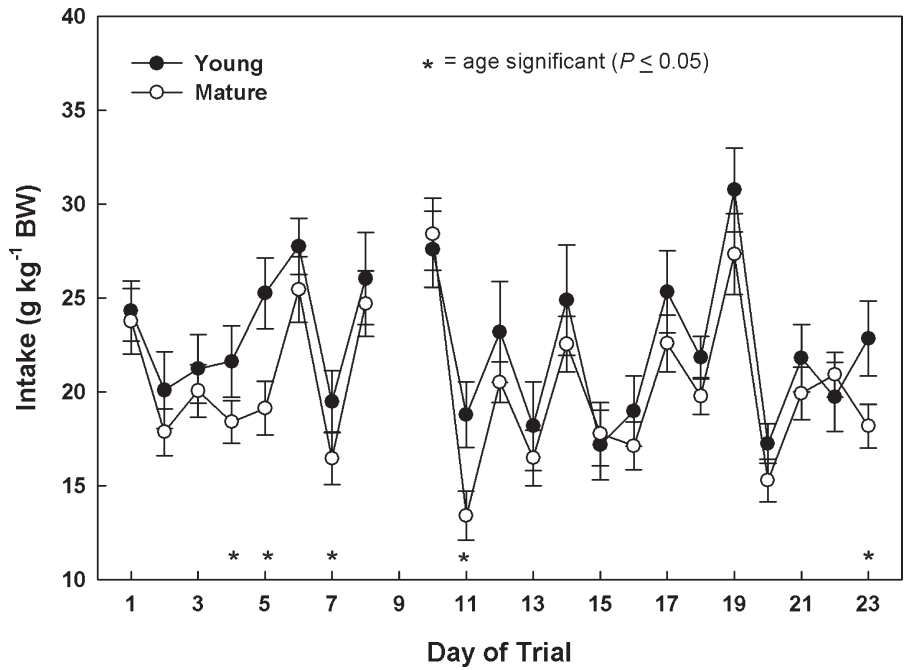

Figure 3. Mean intake of bluegrass pellets treated with $20.8 \mathrm{~g} \cdot \mathrm{kg}^{-1}$ of a monoterpene mixture. The treated pellets were offered in excess for $4 \mathrm{hr}$ for 23 consecutive days. Treatments were young ( $2 \mathrm{yr}$ old) and mature $(>6 \mathrm{yr}$ old). Day 9 was not included in analysis because of limited terpene availability. BW indicates body weight.

overall (Lopez-Ortiz et al. 2007). Additionally, cattle in LBC consumed more ponderosa pine (Pinus ponderosa P. \& C. Lawson) needles than those in average body condition (Launchbaugh et al. 2007). Mellado et al. (2004) found that goats in LBC included a higher proportion of low quality and chemically defended shrubs in their diet than goats in HBC. These studies support our finding of LBC goats eating more juniper and terpene-treated feed than HBC goats when the basal ration was capped and no other alternative forages were available.

However, although animals in LBC are more likely to consume toxic plants, they may not be as capable of metabolizing the toxins found in those plants. Foley et al. (1995) contends that browsing ruminants under nutritional stress must alter their foraging behavior to decrease the intake of toxic shrubs to maintain systemic acid-base homeostasis. Failure to do so would result in additional weight loss from the break down of muscle tissue to generate bicarbonate for buffering the increased acid load resulting from toxin metabolism. Illius and Jessop (1995) also predict that animals on a high plane of nutrition should be able to consume greater amounts of plants containing allelochemicals than animals with lower nutrient intakes. For example, Wang and Provenza (1996) found that the greater the level of food deprivation, the lower the consumption of foods containing LiCl. Additionally, Strickland et al. (1998) discovered that animals on a low plane of nutrition exhibit more signs of toxicity when consuming snakeweed (Gutierrezia spp.). Lopez-Ortiz et al. (2004) reported that sheep in moderate or LBC expressed higher blood alkaloid levels than sheep in HBC when dosed with silvery lupine (Lupinus argenteus Pursh), an alkaloid-containing plant.

However, we found that LBC goats in experiment 2 were not only capable of maintaining a high level of intake of a toxic food, but they were also capable of gaining weight $\left(+2.09 \mathrm{~kg} \cdot\right.$ animal $\left.^{-1}\right)$ over the course of the 22-d trial. This indicates that metabolism of the four monoterpenes did not 
leave the animals in an energy deficit, despite the high concentration of monoterpenes (twice the amount found on redberry juniper foliage), the relatively low quality of the bluegrass pellets and the limited amount of alfalfa pellets $(1.5 \%$ BW). Dziba et al. (2006) found that dosing sheep in the rumen with 1,8-cineole (a monoterpene found in sagebrush) did not affect the acid-base balance of sheep. This suggests that terpene metabolism does not significantly alter acid:base homeostasis so that additional energy is not required for metabolism processes. Additionally, cattle in LBC gained weight on a limited basal ration $(1.5 \% \mathrm{BW})$ while consuming more ponderosa pine needles than animals in average body condition (Launchbaugh et al. 2007). Koong et al. (1985) and Ferrell et al. (1986) demonstrated that nutritionally deprived animals decrease blood flow and activity of visceral organs, thereby lowering their basal metabolism and consequently decreasing maintenance requirements. If the LBC goats in our trial had lower basal metabolic rates, then the limited basal ration may have offered sufficient nutrients to facilitate detoxification and result in weight gain. Dietary supplements including protein (Villalba et al. 2002) and energy (Banner et al. 2000) have been shown to increase consumption of monoterpene-laden plants. Supplementation is more effective at increasing intake of toxic plants when ingestion of the supplement is closely associated in time with ingestion of the toxic meal (Villalba et al. 2006). It is unlikely that energy can be obtained from catabolism of fat at the same rate as that provided by a supplement that is ingested simultaneously with the toxin. Therefore, the fat reserves of the animals in HBC may not have provided effective energy for detoxification.

Intake of the monoterpene-treated feed in experiment 2 was four times greater than that of redberry juniper foliage in experiment 1 by all treatment groups, despite the fact that the monoterpene treated feed contained twice the amount of monoterpenes as foliage. However, redberry juniper contains a much wider array of monoterpenes than the four used in experiment 2 (Owens et al. 1998). Similar studies by Estell et al. $(1998,2000,2002,2005)$ examined the influence of 19 individual monoterpenes on the consumption of alfalfa pellets treated with up to 10 times the amount of the compounds naturally occurring on tarbrush (Flourensia cernua). Only 4 of the 19 monoterpenes influenced consumption of alfalfa pellets when examined individually. However, when alfalfa pellets were treated with extracts of the entire suite of chemicals found in tarbrush, sheep reduced intake of the alfalfa pellets. The findings of Estell et al. (1998, 2001, 2002) and the results of experiment 2 suggest that the natural composition of monoterpenes in vegetation has a greater influence on intake than the concentration of individual monoterpenes.

Young animals consumed more juniper and terpene-treated feed than mature goats. Young animals have higher nutritional requirements and consequently select diets that are higher in nutrients than mature animals, when possible (Cazcarra and Petit 1995; Grings et al. 2001). However, age-related differences in diet selection are generally only evident when comparing juveniles $(<2 \mathrm{yr})$ to adults $(>2 \mathrm{yr})$. All of the goats in this study were $\geq 2$ yr old, therefore, the greater consumption of juniper and terpene treated feed may have been caused by a decline in the physiological function of the older goats. Young (1997) contends that aging results in a progressive decline in the function of many physiological systems, primarily because of loss of tissue in the visceral organs. Age-related tissue loss negatively affects the animal's ability to regulate homeostasis, including regulation of acid:base balance and its ability to deal with biological challenges. This impairment is only evident when the animal's physiological system is challenged by a toxic substance, i.e., monoterpenes (Young 1997). The lower intake of juniper and terpene-treated feed by the older goats could be caused by a decrease in the ability of those animals to detoxify the monoterpenes.

\section{MANAGEMENT IMPLICATIONS}

Animals grazing rangelands undergo natural fluctuations in body condition related to forage availability and reproductive cycle. It is important to recognize that the diet of animals in LBC may vary in total amount consumed and in species composition from that of animals in HBC. Consequently, the state of the animal should be considered when making grazing management decisions. For example, our research suggests that calculating stocking rate based on intake as a percent of body weight may lead to excessive stocking rates for animals in LBC. Additionally, young grazing animals should have sufficient alternative forage available to prevent excessive consumption of chemically defended plants. The management of age and body condition may also be an important part of implementing prescribed grazing plans aimed at controlling chemically defended plants. Livestock managers may stratify herds according to age or maintain animals in moderate or LBC to maximize intake of monoterpene containing plants.

\section{LITERATURE CITED}

Arnold, G. W., And H. A. Birrell. 1977. Food intake and grazing behaviour of sheep varying in body condition. Animal Production 24:343-353.

Banner, R. E., J. Rogosic, E. A. Butritt, and F. D. Provenza. 2000. Supplemental barley and charcoal increase intake of sagebrush by lambs. Journal of Range Management 53:415-420.

Bines, J. A., and S. V. Morant. 1983. The effect of body condition on metabolic changes associated with intake of food by the cow. British Journal of Nutrition 50:81-89.

Cazcarra, R. F., and M. Petit. 1995. The influence of animal age and sward height on the herbage intake and grazing behavior of Charolais cattle. Animal Science (Pencaitland) 61:497-506.

Dunn, R. W., K. M. Havstad, and E. L. Ayers. 1988. Grazing behavior responses of rangeland beef cows to winter ambient temperatures and age. Applied Animal Behaviour Science 21:201-207.

Dye, K. L., II, D. N. Ueckert, and S. G. Whisenant. 1995. Redberry juniperherbaceous understory interactions. Journal of Range Management 48:100-107.

Dziba, L. E., J. 0. Hall, and F. D. Provenza. 2006. Feeding behavior of lambs in relation to kinetics of 1,8-cineole dosed intravenously or into the rumen. Journal of Chemical Ecology 32:391-408.

Estell, R. E., E. L. Frederickson, D. M. Anderson, K. M. Havstad, and M. D. Remmenga. 2000. Effect of individual terpenes on consumption of alfalfa pellets by sheep. Journal of Animal Science 78:1636-1640.

Estell, R. E., E. L. Frederickson, D. M. Anderson, K. M. Havstad, and M. D. Remmenga. 2002. Effects of four mono- and sesquiterpenes on consumption of alfalfa pellets by sheep. Journal of Animal Science 80:3301-3306. 
Estell, R. E., E. L. Frederickson, D. M. Anderson, and M. D. Remmenga. 2005. Effects of $\gamma$-terpinene, terpinolene, $\alpha$-copaene, and $\alpha$-terpinene on consumption of alfalfa pellets by sheep. Journal of Animal Science 83:1967-1971.

Estell, R. E., E. L. Frederickson, M. R. Tellez, K. M. Havstad, W. L. Shupe, D. M. Anderson, and M. D. Remmenga. 1998. Effects of volatile compounds on consumption of alfalfa pellets by sheep. Journal of Animal Science 76:228-233

Estell, R. E., M. Tellez, E. Fredrickson, D. Anderson, K. Havstad, and M. Remmenga. 2001. Extracts of Flourensia cernua reduce consumption of alfalfa pellets by sheep. Journal of Chemical Ecology 27:2275-2285.

Ferrell, C. L., L. J. Koong, and J. A. Nienaber. 1986. Effect of previous nutrition on body composition and maintenance energy costs of growing lambs. British Journal of Nutrition 56:595-605.

Foley, M. J., S. McLean, And S. J. CoRk. 1995. Consequences of biotransformation of plant secondary metabolites on acid-base metabolism in mammals: a final common pathway? Journal of Chemical Ecology 21:721-743.

Frost, R. A. 2005. Age and body condition of goats influences consumption of redberry juniper (Juniperus coahuilensis) and disposition of four monoterpenes [dissertation]. Moscow, ID, USA: University of Idaho. $34 \mathrm{p}$.

Garnsworthy, P. C., AND J. H. Topps. 1982. The effect of body condition of dairy cows at calving on their food intake and performance when given complete diets. Animal Production 35:113-119.

Grings, E. E., R. E. Short, M. R. Haferkamp, and R. K. Heitschmidt. 2001. Animal age and sex effects on diets of grazing cattle. Journal of Range Management 54:77-81.

Hayirli, A., R. R. Grummer, E. V. Nordheim, and P. M. Crump. 2002. Animal and dietary factors affecting feed intake during the prefresh transition period in Holsteins. Journal of Dairy Science 85:3430-3443.

HenRY, C. J. K. 2000. Mechanisms of changes in basal metabolism during ageing. European Journal of Clinical Nutrition 54:S77-S91.

Hodgson, J., And W. S. Jamieson. 1981. Variations in herbage mass and digestibility, and the grazing behaviour and herbage intake of adult cattle and weaned calves. Grass and Forage Science 36:39-48.

Huston, J. E., B. S. Rector, L. B. Merrill, and B. S. Engdahl. 1981. Nutritional value of range plants in the Edwards Plateau region of Texas. College Station, TX, USA: Texas A\&M University Experimental Station Bulletin B-1357.

IlLIUS, A. W., AND N. S. Jessop. 1995. Modeling metabolic costs of allelochemical ingestion by foraging herbivores. Journal of Chemical Ecology 21:693-719.

Koong, L. J., C. L. Ferrell, and J. A. Nienaber. 1985. Assessment of interrelationships among levels of intake and production, organ size and fasting heat production in growing animals. Journal of Nutrition 115:1383-1390.

LanglandS, J. P. 1968. Studies on the nutritive value of the diet selected by grazing sheep. Animal Production 11:369-378.

Launchiaugh, K. L., J. A. Pfister, S. Lopez-Ortiz, and R. A. Frost. 2007. Body condition affects blood alkaloid and monoterpene kinetics and voluntary intake of chemically-defended plants by livestock. In: K. E. Panter, T. L. Wierenga, and J. A. Pfister [EDs.]. Poisonous plants: global research and solutions. Wallingford, Oxon, United Kingdom: CABI Publishing. p. 461-467.

Lopez-Ortiz, S., K. E. Panter, J. A. Pfister, and K. L. Launchbaugh. 2004. The effect of body condition on disposition of alkaloids from silvery lupine (Lupinus argenteus Pursh) in sheep. Journal of Animal Science 82:2798-2805.

Lopez-Ortiz, S., J. A. Pfister, K. L. Launchbaugh, and C. C. Gay. 2007. Forage availability and body condition affect intake of lupine (Lupinus leucophyllus) by grazing cattle. The Professional Animal Scientist 23:459-466.

McPherson, G. R., And H. Wright. 1990. Effects of cattle grazing and Juniperus pinchottii canopy cover on herb cover and production in western Texas. American Midland Naturalist 123:144-151.

Mellado, M., A. Rodriguez, J. A. Villarreal, R. Rodriguez, J. Salinas, and R. Lopez. 2004. Gender and tooth wear effects on diets of grazing goats. Small Ruminant Research 57:105-114.

Nagy, J. G., And R. P. Tengerdy. 1968. Antibacterial action of essential oils of Artemisia as an ecological factor. Applied Microbiology 16:441-444.
Noziere, P., D. Attaix, F. Bocoler, and M. Doreau. 1999. Effects of underfeeding and refeeding on weight and cellularity of splanchnic organs in ewes. Journal of Animal Science 77:2279-2290.

OH, H. K., M. B. JONES, AND W. M. LoNGHURST. 1968. Comparison of rumen microbial inhibition resulting from various essential oils isolated from relatively unpalatable plant species. Applied Microbiology 16:39-44.

OH, H. K., T. Sakal, M. B. Jones, and W. M. LonghuRst. 1967. Effects of various essential oils isolated from Douglas Fir needles upon sheep and deer rumen microbial activity. Applied Microbiology 15:777-784.

Owens, M. K., E. J. Straka, C. J. Carroll, and C. A. Taylor, Jr. 1998. Technical note: a comparison of techniques for extracting monoterpenoids from Juniperus (Cupressaceae) species. Journal of Range Management 51:540-544.

Pritz, R. K., K. L. Launchbaugh, and C. A. Taylor, Jr. 1997. Effects of breed and dietary experience on juniper consumption by goats. Journal of Range Management 50:600-606.

Provenza, F. D., and J. C. Malechek. 1986. A comparison of food selection and foraging behavior in juvenile and adult goats. Applied Animal Behaviour Science 16:49-61.

Riddle, R. R., C. A. Taylor, M. M. Kothmann, and J. E. Huston. 1996. Volatile oil contents of ashe and redberry juniper and its relationship to preference by Angora and Spanish goats. Journal of Range Management 49:35-41.

SAS [COMPUTER PRogram]. 2004. SAS procedures guide. Version 9.1. 3rd ed. Cary, NC, USA: SAS Institute.

SiBBaLD, A. M. 1997. The effect of body condition on the feeding behaviour of sheep with different times of access to food. British Society of Animal Science 64:239-246.

Sibbald, A. M., and W. G. Kerr. 1994. The effect of body condition and previous nutrition on the herbage intakes of ewes grazing autumn pastures at two sward heights. Animal Production 58:231-235.

SPAHR, L. I. 2004. Body condition scoring in meat goats. Available at: http:// bedford.extension.psu.edu/agriculture/goat/Body\%20Condition\%20Scoring.htm. Accessed 27 August 2007.

Sprinkle, J. E., J. W. Holloway, B. G. Warrington, W. C. Ellis, J. W. Stuth, T. D. A. Forbes, AND L. W. GREenE. 2000. Digesta kinetics, energy intake, grazing behavior, and body temperature of grazing beef cattle differing in adaptation to heat. Journal of Animal Science 78:1608-1624.

Strickland, J. R., L. F. Gulino-Klein, T. T. Ross, S. Slate, M. K. Peterson, T. May, and J. B. TAYLOR. 1998. Effects of nutrient supplementation in beef cows of poor body condition fed snakeweed (Gutierrezia spp.) Veterinary and Human Toxicology 40:278-284.

SweEney, R. A. 1989. Generic combustion method for determination of crude protein in feeds: collaborative study. Journal of Association of Official Analysis of Chemicals 72:770-774.

Van Soest, P. J., J. B. Robertson, and B. A. Lewis. 1991. Methods for dietary fiber, neutral detergent fiber, and non-starch polysaccharides in relation to animal nutrition. Journal of Dairy Science 74:3583-3597.

Villalba, J. J., F. D. Provenza, and R. E. Banner. 2002. Influence of macronutrients and activated charcoal on intake of sagebrush by sheep and goats. Journal of Animal Science 80:2099-2109.

Villalba, J. J., F. D. Provenza, and R. Shaw. 2006. Initial conditions and temporal delays influence preference for foods high in tannins and for foraging locations with and without foods high in tannins by sheep. Applied Animal Behaviour Science 97:190-205.

Vourc'h, G., M. Degarine-Wichatitsky, A. Labbe, D. Rosolowski, J. Martin, and H. Fritz. 2002. Monoterpene effect of feeding choice by deer. Journal of Chemical Ecology 28:2411-2427.

Wang, J., and F. D. Provenza. 1996. Food deprivation affects preference of sheep for foods varying in nutrients and a toxin. Journal of Chemical Ecology 22:2011-2021.

Young, A. 1997. Ageing and physiological functions. Philosophical Transactions of the Royal Society of London 352:1837-1843. 